\title{
Yağ Asitlerinin İnflamasyonla İlişkili Süreçlere Etkisinin Değerlendirilmesi
}

\author{
Evaluation of the Effects of Fatty Acids on Inflammation Processes
}

\section{Zeynep Uzdil' ${ }^{1}$ Mendane Saka ${ }^{2}$}

Geliş tarihi/Received: 03.06.2020 • Kabul tarihi/Accepted: 22.09.2020

\section{ÖZET}

Metabolik süreçlerin devamında ve pek çok hastalığın ortaya çıkışında inflamasyonun önemli bir rol oynadığı bilinmektedir. Konağın enfeksiyona karşı verdiği inflamatuvar yanıtlar; immün hücreler, çeşitli inflamatuvar aracılar, transkripsiyon faktörleri ve nükleer reseptörler aracılığı ile olmaktadır. Yağ asitleri konağın inflamatuvar yanıtının düzenlenmesi ve homeostazın sağlanmasında işlev gören aracılardan biridir. Güncel çalışmalar ile yağ asitlerinin inflamasyon üzerine etkilerini gösteren sonuçlar ortaya konulmuştur. Özellikle çoklu doymamış yağ asitlerinin eikozanoidlere dönüşümü ile yağ asitleri inflamatuvar yanıt sürecine katılmaktadır. Omega-6 yağ asidi kaynaklı araşidonik asidin proinflamatuvar, omega-3 yağ asidi kaynaklı EPA ve DHA’nın ise antiinflamatuvar özellikleri bilinmektedir. Bu derlemede, yağ asitlerinin inflamatuvar süreçlere etkisinin değerlendirilmesi amaçlanmıştır.

Anahtar kelimeler: İnflamasyon, yağ asitleri, eikozanoidler

\begin{abstract}
It is known that inflammation plays an important role in the progression of metabolic processes and the development of many diseases. Inflammatory responses of the host to infection are mediated by immune cells, various inflammatory mediators, transcription factors and nuclear receptors. Fatty acids are agents that function in regulating host immune response and maintaining homeostasis. Current studies show the effects of fatty acids on inflammation. Fatty acids involved in the inflammatory responses, especially with the transformation of polyunsaturated fatty acids to eicosanoids. It is known that arachidonic acid derived from omega-6 have proinflammatory properties and EPA-DHA derived from omega-3 have antiinflammatory properties. The aim of this review was to investigate the effects of fatty acids on inflammatory processes.
\end{abstract}

Keywords: Inflammation, fatty acids, eicosanoids

1. İletişim/Correspondence: Ondokuz Mayıs Üniversitesi, Sağllk Bilimleri Fakültesi, Beslenme ve Diyetetik Bölümü, Samsun, Türkiye • E-posta: zuzdil1010@hotmail.com 으 https://orcid.org/0000-0002-8152-5858
2. Başkent Üniversitesi, Sağlık Bilimleri Fakültesi, Beslenme ve Diyetetik Bölümü, Ankara, Türkiye

(i) https://orcid.org/0000-0002-5516-426X 


\section{GíRiş}

İnflamasyon, enfeksiyona karşı konağın verdiği savunma mekanizması olarak tanımlanır ve patojenlerin öldürülmesi ile başlattığı etkinliğini, dokuların onarımı ile sürdürerek vücutta enfekte olmuş yapıların homeostazını sağlar (1). Vasküler duvar geçirgenliğinin artışı, inflamasyon bölgesine plazma ve büyük moleküllerin geçişine olanak sağlar (2). Konağın bu savunma mekanizmasında; makrofajlar, dendritik hücreler, mast hücreleri, nötrofiller, eozinofiller, doğal öldürücü hücreler (doğuştan gelen bağışıklık) bunun yanında $\mathrm{B}$ ve $\mathrm{T}$ lenfositlerin aracılığı ile CD4+, CD8+, doğal öldürücü T hücreleri (sonradan kazanılmış bağışıklık) rol oynar (3). Ayrıca, bu savunma mekanizması çok sayıda kimyasal aracıyı üretmeyi ve bunlara yanıt vermeyi içerir (1).

İnflamatuvar süreç; antiinflamatuvar sitokinlerin salgılanması, proinflamatuvar sinyallerin önlenmesi ve inflamatuvar aracıların bağlanacağı reseptörlerin kayba uğramasını içeren negatif feedback mekanizmaları ile düzenlenebilir. Fakat bu düzenleyici mekanizmaların yetersiz olması ve inflamasyonun devam etmesi konakçı dokularda onarılamaz hasara neden olabilir (2). Bu sebeplerden dolayı romatoid artrit, sedef hastalığı, Crohn hastalığı, alerjik astım ve atopik dermatit gibi çeşitli hastalıkların patolojisinde ve hastalıklarda görülen doku hasarında inflamasyonun önemli rol oynadı̆̆ı bilinmektedir (1). İnflamatuvar yanıt sıklıkla geçici olmakla birlikte akut yanıt bazı koşullarda kronikleşebilir (4). Uzun süre kronik inflamasyona maruziyet kardivasküler hastalıklar, tip 2 diyabet, obezite, nörolojik hastalıklar ve kanserin içinde bulunduğu kronik hastalıkların ortaya çıkışında önemli etkinlik gösterir $(1,4)$.

İflamatuvar savunma sürecinde üretilen bazı kimyasal aracılar ve onlara ait öncüller yer almaktadır (Tablo 1) (2). Bu kimyasal aracılardan lipit kaynaklı olan ve elzem yağ asitleri linoleik ve linolenik asit türevlerinden oluşan eikozanoidler inflamatuvar yanıtta rol oynamaktadır (5). Diyetin yağ asidi örüntüsünün inflamasyon üzerine farklı etkilerinin olduğu, doymuş yağ asitlerinin hastalık gelişimini tetikleyici proinflamatuvar etki gösterirken, omega-6 çoklu doymamış yağ asitlerinin hastalık oluşumundaki ara basamakları inhibe ettiği gösterilmiştir (6). Diyetin doymuş yağ asidi içeriğinin omega-6 çoklu doymamış yağ asidi ile değişiminin koroner kalp hastalığına bağlı sorunları ve buna bağlı mortaliteyi azalttığı bir metaanaliz çalışmasında gösterilmiştir (7). Yağ asitlerinin inflamatuvar süreçte gösterdikleri etkinliklerinin, kronik hastalıkların oluşumuna kadar varan sonuçları olmaktadır. $\mathrm{Bu}$ nedenle bu derlemede, güncel literatürün araştırılması sonucunda yağ asitlerinin inflamatuvar süreçlere etkisinin değerlendirilmesi amaçlanmıştır.

\section{Yağ Asitleri ve İnflamasyon}

Yağ asitleri bir ucunda bir metil grubu diğer ucunda bir karboksil grubu içeren asitler olup çift bağların varlığına bağlı olarak, çift bağ içermeyen-doymuş yağ asitleri, bir çift bağ içeren-tekli doymamış yağ asitleri ve en az iki çift bağ içeren-çoklu doymamış yă̆ asitleri olarak sinıflandırılırlar (8). Yağ asitleri, enerji vermeleri ve hücre yapısına katılmaları yanında gen ekspresyonlarını düzenlemede de rol alırlar (9). Nükleer reseptörlerden olan peroksizom proliferatör aktive edilmiş reseptörler (PPARs) gen ekspresyonu yoluyla lipid metabolizmasını düzenlerler ve vücutta

Tablo 1. İnflamatuvar savunma sürecinde üretilen bazı kimyasal aracılar ve öncüleri (2)

\begin{tabular}{ll}
\hline Öncü bileşenler & Kimyasal aracilar \\
\hline \multirow{2}{*}{ Lipitler } & Prostaglandinler \\
& Lökotrienler \\
& Endokannabinoidler \\
& Platelet aktive edici faktör \\
& Sitokinler \\
Peptitler & Kemokinler \\
& Histamin \\
Amino asit & Nitrik oksit \\
& Süperoksit anyonu \\
Reaktif oksijen türleri & Hidrojen peroksit \\
Enzimler & Matriks proteazlar \\
\hline
\end{tabular}


işlev görmek için lipid yapısındaki eikozanoidler gibi spesifik bir liganda bağlanırlar (10).

\section{Doymuş Yağ Asitleri}

Doymuş yağ asitleri, $\mathrm{T}$ hücre aktivasyonu ile proinflamatuvar yolların uyarılmasını sağlayan Toll-4 reseptörü ile etkileşimde olması, adipozitlerde proinflamatuvar sitokinlerin salınıminı uyaran nükleer transkripsiyon faktör kappa B’yi (NF-kB) aktive etmesi, hücre içi sinyal ileticileri Jun N-terminal kinaz proteininin fosforilasyonunu ve protein kinaz C aktivitesini uyarması sebebiyle inflamasyon sürecinde önemli etkiler gösterir $(3,11)$. Orta düzey diş iltihabi olan 40 yaş üzeri bireylerin eritrositlerinde palmitik ve stearik asidi içeren doymuş yağ asidinin bir birimlik artışının interlökin-6 (IL-6) düzeyinde \%15 kadar artışa neden olduğu gösterilmiştir (12). Doymuş yağın inflamasyona yol açmasındaki olası mekanizmanın, bağırsakta bakteriyel kaynaklı lipopolisaklaritlerin üretimi aracılığı ile olduğu bildirilmektedir (9). Lipopolisakkaritler, Toll 2 ve 4 reseptörlerine bağlanarak ve seramid üretimini uyararak inflamatuvar süreci başlatırlar. Makrofaj ve adipositlerde bulunan Toll-4 reseptörler, NF-кB’nin çekirdeğe translokasyonunu kolaylaştırırlar (9).

\section{Çoklu Doymamış Yağ Asitleri}

Çoklu doymamış yağ asitlerinin inflamasyonla ilişkisi eikozanoidlerin üretimi aracılığı ile

Araşidonik asit

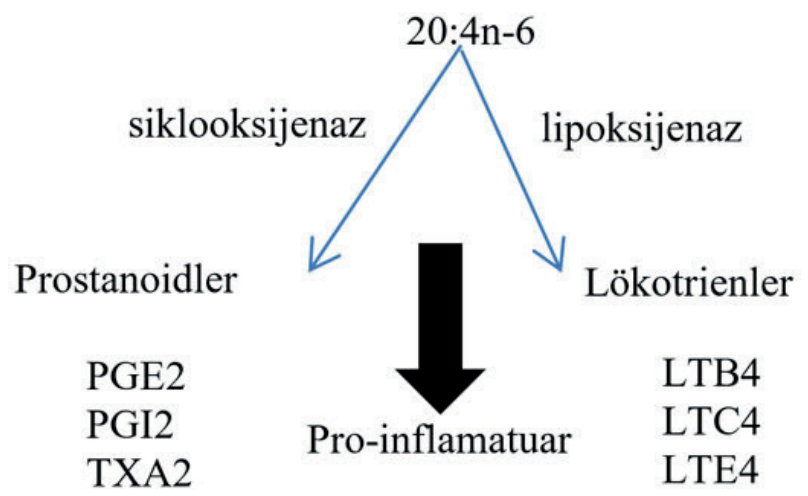

olmaktadır. Eikozanoid sentezi hücre membranında fosfolipitlerden fosfolipaz A2 enzimi ile elde edilen çoklu doymamış yağ asitleri aracılığıyla olur (14). Sentezlenen bu bileşenler prostaglandinler (PG), prostasiklinler (PGI), tromboksanlar (TX), lökotrienler (LT), hidroperoksitetraenoik asit (HPETE), hidroksieikozatetranoik asit (HETE) ve lipoksinlerdir. Çoklu doymamış yağ asitlerinin eikozanoidlere dönüşümü siklooksijenaz (COX), sitokrom P450 (CYP 450) ve lipoksigenaz (LOX) enzim katalizörlüğünde olur (13). Prostaglandinler, prostasiklinler ve tromboksanlar prostanoidler olarak da bilinirler. Prostanoid-2 serisi ile LT-4 serisi araşidonik asitten, prostanoid-3 serisi ve LT-5 serisi eikozapentaenoik asitten üretilirler (14). Eikozanoidler olarak adlandırılan immün düzenleyicilerin inflamasyon, trombosit agregasyonu, immün yanıt, hücre büyümesi ve proliferasyonu, düz kas hücrelerinin genişlemesi ve kontraksiyonunu düzenleyici işlevleri vardır (14).

Diyetin çoklu doymamış yağ asit örüntüsünün inflamasyon üzerine etkisini değerlendiren deneysel bir çalışmada, omega-6/omega-3 oranının azaltılması amacıyla omega-3 yağ asidi ile zenginleştirilmiş tereyağının etkisine bakılmıştır (15). Buna göre omega-3 destekli yağ tüketenlerin sadece tereyağ 1 veya margarin tüketen ratlara göre NF$\kappa \mathrm{B}$ aktivasyonunda azalma gözlenirken, margarin alan grupta proinflamatuvar etkili tümör nekroz faktör alfanın (TNF- $\alpha$ ) mRNA ekspresyonunda artış saptanmıştır. Çoklu doymamış yağ asitlerinin koroner

Eikozapentaeonik asit

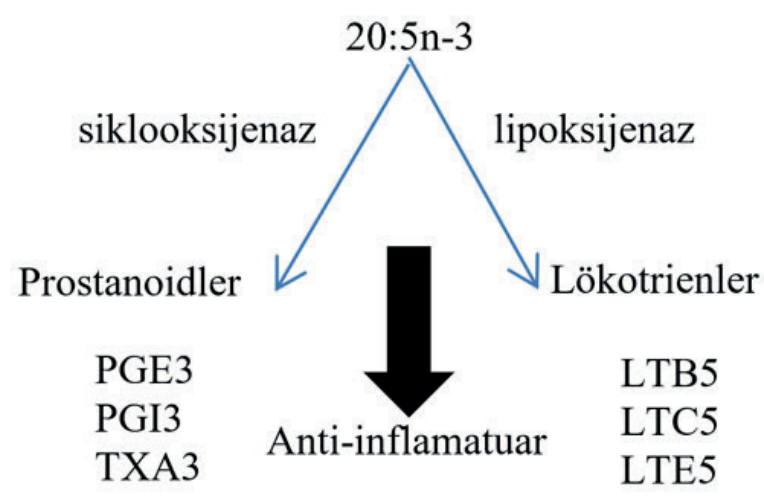

PG: Prostaglandin, TX: Tromboksan, LT: Lökotrien

Şekil 1. Eikozanoidlerin öncüsü olarak omega-6 ve omega-3 yağ asitlerinin metabolitleri (13. kaynaktan uyarlanmıştır) 
Tablo 2. Omega-3 yağ asitlerinin antiinflamatuvar etkileri (18-20)

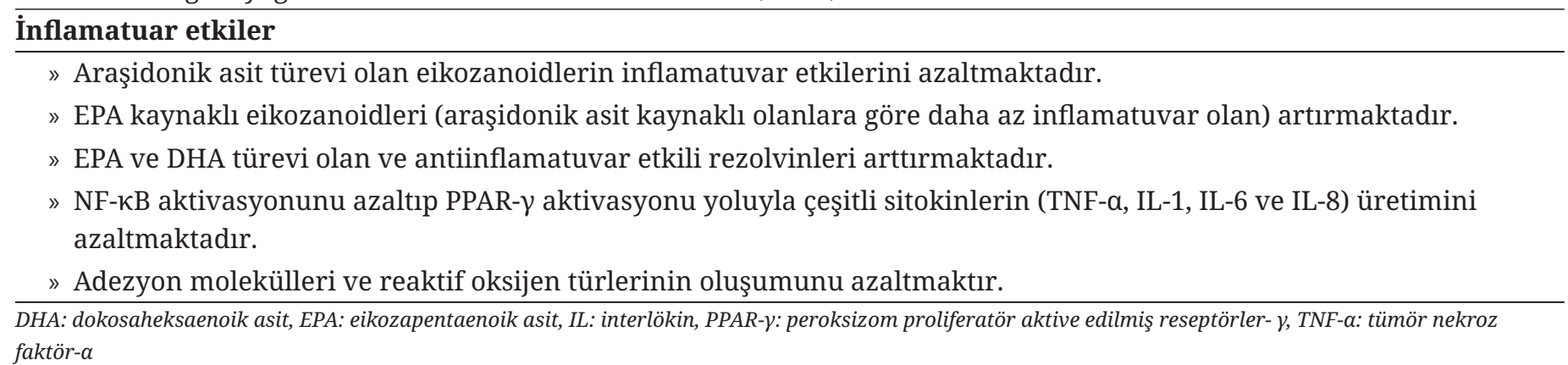

arter hastalarındaki düzeyi ve etkilerinin sağlıklı bireylerden oluşan kontrol grubuyla kıyaslandığı çalışmada, hastaların serum omega-6/omega-3 oranının yüksek olduğu saptanmıştır. Ayrıca yüksek DHA düzeyinin koroner arter hastalığı olan bireylerde inflamasyonu baskılayabileceği gösterilmiştir (16).

Omega-3 yağ asitleri: Uzun zincirli çoklu doymamış yağ asitlerinden elzem olan a-linolenik asitten sentezlenen eikozapentaenoik asit (EPA, 20:5, $\omega-3$ ) ve dokosaheksaenoik asit (DHA, 22:6, $\omega$-3) hücresel fonksiyonlarının yerine getirilmesinde işlev görür (17). Antiinflamatuvar etkileri bilinen omega-3 yağ asitlerinin bu özellikleri Tablo 2'de gösterilmiştir (1820).

Günde 1.8 g/gün EPA ve DHA içeren balık yağı desteğini 26 hafta süre alan 65 yaş ve üzeri bireylerde EPA ve DHA'nın, periferik kan mononükleer hücreleri üzerinde antiinflamatuvar ve antiaterojenik etkiler gösterdiği saptanmıştır (21). Çift kör randomize kontrollü çalışmada, 18-70 yaş arasında sistemik inflamasyonu olan sağlıklı obezlerde, 10 hafta süresince 3 g/gün DHA kullanımının aynı miktarda EPA’ya göre proinflamatuvar IL-18 düzeyini azaltma ve antiinflamatuvar adiponektini arttırma etkisinin daha güçlü olduğu belirlenmiştir (19). Yaşları 45 yıl üzeri ve en az 10 yıldır kardiyovasküler hastalık öyküsü olan bireylerde, diyetle $\geq 1$ g/gün omega-3 yă̆ asidi tüketenlerin, bu miktarın altında tüketenlere göre adiponektin, IL-12 ve IL-1 $\beta$ düzeylerinin düşük olduğu belirlenmiştir. Aynı çalışmada, diyette artan omega-3 ve omega-6 yağ asitleri miktarının CRP, IL12 ve IL-1 $\beta$ 'yi içeren inflamatuvar belirteçlerde azalmaya yol açtığı gösterilmiştir (11). EPA ve DHA'nın hem normal hem de inflamatuvar koşullar altında insan safenöz damar tonusunu azalttığ gösterilmiş ve proiinflamatuvar düzenleyicilerde de azalma kaydedilmiştir (22). İleri yaştaki fazla kilolu (23) ve genç (24) bireylere verilen omega-3 yağ asidi desteğinin inflamatuvar belirteç düzeyini olumlu yönde etkileyerek inflamasyonu azalttığı gösterilmiştir. Yaşları 20-45 yıl arasında olan sağlıklı bireylerde EPA ve DHA içeren omega-3 yağ asidi desteğinin etkisi değerlendirildiğinde, IL-6 ve CRP düzeyleri etkilenmez iken 1800 mg/gün omega-3 desteğinin TNF- $\alpha$ düzeyinde azalmaya yol açtığı belirlenmiştir. Ancak bu doz besinlerle alınabilecek düzey olmadığı için bu etkinin destek olarak verildiğinde görüldüğü vurgulanmıştır (25).

Omega-3 yağ asitlerinin antiinflamatuvar etkileri gebeler üzerinde de çalışılmıştır. Gebelere, 25 hafta süresince $0.8 \mathrm{~g}$ DHA ve $1.2 \mathrm{~g}$ EPA olmak üzere toplam 2.0 g omega-3 yağ asidi verilen çift kör çalışmada, adipoz dokuda inflamatuvar genlerin ekspresyonunda azalmanın olduğu belirlenmiştir (26). Gebe ratlarda yapılan omega-3 desteğinin, gebenin plazması ve plasentada proinflamatuvar sitokin düzeyinde azalmaya, antiinflamatuvar sitokin düzeyinde artışa yol açtığı gösterilmiştir (27).

Dasilva et al. (28), farklı kaynaklı EPA ve DHA desteğinin ratlarda inflamatuvar belirteçlere etkisini araştırmışlardır. Buna göre 5 farklı diyet grubunda soya fasülyesi, keten tohumu ve zenginleştirilmiş yağ (EPA:DHA oranı 1:1; 1:2 ve 2:1 olan $0.8 \mathrm{mg} / \mathrm{kg} /$ hafta içeren deniz ürünleri kaynaklı zenginleştirme) 
kullanımının etkileri değerlendirilmiştir. Çalışmanın sonuçlarına göre EPA:DHA oranı 1:1 ve 2:1 olması diğer gruplara göre inflamasyon ve oksidatif stresi azaltmada daha etkili görülmüştür. Ayrıca EPA'nın DHA'ya göre ve deniz kaynaklı omega-3 yağ asidinin bitkisel kaynaklıya göre daha fazla antiinflamatuvar özellik gösterdiği saptanmıştır. Başka bir çalışmada, deneysel olarak kolit oluşturulan ratlara verilen bitkisel kaynaklı a-linolenik asidin balık yağına göre inflamatuvar etkinliği gösterilmiştir. Hayvansal kaynaklı omega-3'ün antiinflamatuvar etkinliğinin fazla olmasının yanında antikoagülan etkileri de bilinmektedir. Bitkisel kaynaklı yağ asitlerinin özellikle antikoagülan tedavisi alan veya kanama sorunları yaşayan inflamatuvar bağırsak hastalarına uygun olabileceği düşünülmektedir (29). Dislipidemisi olan, fazla kilolu ve/veya obez olan ratlarda, 12 hafta süresince 2 gram omega-3 yağ asidi ve siklooksijenaz enzim inhibitörünün kombine uygulamasının adipoz doku inflamasyonu üzerine olumlu etkisigösterilmiştir (30). Literatürdeki insan ve rat çalışmaları, farklı yaş grupları, sağlık sorunu olmayan veya inflamasyonla ilişkili hastalığı olanlarda omega-3 kaynaklı çoklu doymamıs yağ asitlerinin antiinflamatuvar etkilerini göstermektedir.

Omega-6 yağ asitleri: Elzem yağ asidi olan linolenik asitten sentezlenen araşidonik asit de EPA gibi eikozanoidlerin yapısına girer. Eikozanoid üretimi için öncü olan araşidonikasit, hücrelerinuyarılmasısonucu membran fosfolipitlerinden salınır (18). Araşidonik asitten siklooksijenaz (COX) yolu ile prostaglandin ve tromboksan, lipoksijenaz (LOX) yoluyla lökotrien ve lipoksin, sitokrom P450 monooksijenazlar (CYP) yolu ile hidroksieikozatetraenoik asitler (HETE) ve epoksi-eikozatrienoik asitler (EET) oluşur. COX ve LOX yoluyla üretilen eikozanoidler inflamatuvar yanıtı başlatırken CYP yolu inflamasyon ve vasküler tonusun düzenlenmesinde rol oynayan EET oluşumunu düzenler (20). Araşidonik asitten yapılan eikozanoidler; PGE2, TXA2 ve LTB4'dür. PGE2 hem antiinflamatuvar hem proinflamatuvar etkilidir ve hastalık olmadığı durumlarda homeostazı sağlar. Ateşe neden olması, vasküler geçirgenliği arttırması, vazodilatasyonu arttırması, ağrıya neden olması, kızarıklık ve şişliğe sebep olması gibi proinflamatuvar etkileri bildirilmiştir (18,31). Antiinflamatuvar etkileri ise TNF- $\alpha$ ve IL-1 üretimini inhibe etmesi, 5-LOX'u inhibe ederek 4 serisi LT üretimini azaltması, 15-LOX'u indükleyerek lipoksin üretimini arttırmasıdır. TXA2'nin trombosit agregasyonuna yol açan, vazokonstriksiyon ve hücre proliferasyonunda etkileri vardır (32). LTB4 proinflamatuvar etkili olup vasküler geçirgenliği ve bölgesel kan akışını arttırmakta, lökositler için kemotaktik ajan özelliği göstermekte, lizozomal enzimlerin salınmasını, reaktif oksijen türlerinin granülositlerce salınmasını ve TNF-a, IL-1 ve IL-6 üretimini artırmaktadır (18).

Linoleik asit izomeri olan konjuge linoleik asitin antiinflamatuvar etkilerinden PPAR gamaların sorumlu olduğu bilinmektedir. Çoklu doymamış yağ asitlerinden enzimatik olmayan reaksiyonlardan ve endojen nitrik oksitten sentezlenen nitrat yağ asitleri, antiinflamatuvar özelliktedir. Nitrat yağ asitleri PPAR gamanın endojen olarak bağlandığı bir moleküldür ve antinflamatuvar etkisini PPAR aracılığıyla gösterir (10). Alfa lipoik asidin antioksidan ve antiinflamatuvar özellikleri bilinmekte olup tip 2 diyabetli bireyler ile yapılan çift kör randomize kontrollü bir çalışmada, üç ay süreyle $600 \mathrm{mg}$ verildiğinde CRP düzeylerinin azaldığı saptanmıştır (33). Trans yağ asitleri inflamasyon üzerine etkilerini, NF- $\kappa B$ yolunu uyarıp böylece süperoksit üretiminde artışa, NO üretiminde azalmaya yol açarak göstermektedir (8). İnflamatuvar yanıtta görevli olan makrofaj ve monosit hücrelerini harekete geçiren, TNF- $\alpha$ ve IL-6 üretiminin artışı da trans yağ asitleri sayesinde olur (34). Çoklu doymamış yağ asidi omega-6'nın proinflamatuvar ve antiinflamatuvar özellikleri bilinmektedir. Diyette elzem olmasından dolayı diğer yağlar ile dengeli şekilde alınması önemlidir (13).

\section{Tekli Doymamış Yağ Asitleri}

Omega-9 yağ asitleri: Rodrigues et al. (35) ratlara oral olarak verilen oleik asidin yara iyileşmesi sırasında inflamatuvar yanıta etkisini araştırmışlar ve $0.22 \mathrm{~g} / \mathrm{kg}$ verilen oleik asidin yara iyileşmesinin 
inflamatuvar fazını hızlandırdığını; bunu sitokinlerin (TNF- $\alpha$ ) ve $\mathrm{H}_{2} \mathrm{O}_{2}$ 'in erken üretimi ve transkripsiyon faktör NF-kB aktivasyonu aracılığıyla yaptığını belirlemişlerdir. Diş etinde inflamasyon oluşturulmuş randomize kontrollü bir rat çalışmasında diş çekimi işlemi uygulanmasından önce dört gün ve işlem sonrası üç gün boyunca yağ asitlerinin örüntüsünün inflamatuvar belirteçlere etkisi incelenmiştir. Buna göre yağ asidi örüntüsünde omega-9/omega-6 oranı (3.7/1) yüksek ve omega-6/omega-3 oranı (1.4/1) düşük olan grupta TNF-a düzeyinde önemli bir azalma gözlenmiştir (36).

\section{SONUÇ VE ÖNERILER}

İnflamasyon çeşitli akut ve kronik hastalıklara eşlik eden bir durumdur ve vücutta inflamatuvar sitokinler, araşidonik asit kaynaklı eikozanoidler, adezyon moleküllerinin üretimini içeren metabolik bir yanıt oluşturur. Son yıllarda yapılan insan ve hayvan çalışmalarında, yağ asitlerinin inflamatuvar belirteçler, dolayısı ile inflamatuvar süreçler ile ilişkisi gösterilmektedir. Diyetle alınan omega-3 ve omega-6 çoklu doymamış yağ asitleri inflamasyonda, özellikle eikozanoidlerin yapısına girerek, hücre membranındaki işlevleri ve diğer inflamatuvar belirteçleri etkileme yolu ile etkinlik gösterirler. Bunun yanında doymuş yağların da proinflamatuvar etkinlikleri bilinmektedir. Çoklu doymamış yağ asitlerinin doymuş yă̆ asitlerine, çoklu doymamış yağ asitlerinden omega-3 kaynaklı olanların omega-6 kaynaklıya ve omega-3 kaynaklı yağ asitlerinden EPA'nın DHA’ya göre antiinflamatuvar özellikleri daha fazladır. İnflamasyona bağlı akut hasarların ve kronik hastalıkların önlenmesinde, diyetin yağ asit örüntüsü hakkında veriler sunacak daha fazla klinik araştırmaya ihtiyaç duyulmaktadır.

Çıkar çatışması - Conflict of interest: Yazarlar çıkar çatışması olmadığını beyan ederler. - The authors declare that they have no conflict of interest.

\section{KAYNAKLAR}

1. Calder PC, Ahluwalia N, Albers R, Bosco N, BourdetSicard R, Haller D, et al. Consideration of biomarkers to be used for evaluation of inflammation in human nutritional studies. Br J Nutr. 2013;109:1-34.

2. Innes JK, Calder PC. Omega-6 fatty acids and inflammation. Prostaglandins Leukot Essent Fatty Acids. 2018;132:41-8.

3. Sun S, Ji Y, Kersten S, Qi L. Mechanisms of inflammatory responses in obese adipose tissue. Annu Rev Nutr. 2012;32:261-86.

4. Fritsche KL. The science of fatty acids and inflammation. Adv. Nutr. 2015;6:293-301.

5. Piper K, Garelnabi M. Eicosanoids: Atherosclerosis and cardiometabolic health. J Clin Transl Endocrinol. 2020;19:100216.

6. Sui YH, Luo WJ, Xu QY, Hua J. Dietary saturated fatty acid and polyunsaturated fatty acid oppositely affect hepatic NOD-like receptor protein 3 inflammasome through regulating nuclear factor-kappa B activation. World J Gastroenterol. 2016;22(8):2533-44.

7. Hamley S. The effect of replacing saturated fat with mostly n-6 polyunsaturated fat on coronary heart disease: a meta-analysis of randomised controlled trials. Nutr J. 2017;16(30):1-16.

8. Ghosh A, Gao L, Thakur A, Siu PC, Lai CWK. Role of free fatty acids in endothelial dysfunction. J Biomed Sci. 2017;24:50.

9. Ruiz-Núñez B, Dijck-Brouwer DAJ, Muskiet FAJ. The relation of saturated fatty acids with low-grade inflammation and cardiovascular disease. J Nutr Biochem. 2016;36:1-20.

10. Marion-Letellier R, Savoye G, Ghosh S. Fatty acids, eicosanoids and PPAR gamma. Eur J Pharmacol. 2016;785:44-9.

11. Bersch-Ferreira AC, Sampaio GR, Gehringer MO, RossFernandes MB, Kovacs C, Alves R, et al. Association between polyunsaturated fatty acids and inflammatory markers in patients in secondary prevention of cardiovascular disease. Nutrition. 2017;37:30-6.

12. Mu L, Mukamal KJ, Naqvi AZ. Erythrocyte saturated fatty acids and systemic inflammation in adults. Nutrition. 2014;30:1404-8.

13. Lee S, Gura KM, Kim S, Arsenault DA, Bistrian BR, Puder M. Current clinical applications of $\Omega-6$ and $\Omega-3$ fatty acids. Nutr Clin Pract. 2006;21(4):323-41.

14. FAO-Food and nutrition paper. Fats and fatty acids in human nutrition. Report of an expert consultation. Chapter 8: Fat and fatty acid intake andinflammatory and immune response. 2010;91:91-9.

15. Fan R, Kim J, You M, Giraud D, Toney AM, Shin S-H, et al. a-linolenic acid-enriched butter attenuated high fat diet-induced insülin resistance and inflammation by promoting bioconversion of n-3 PUFA and subsequent oxylipin formation. J Nutr Biochem. 2020;76:108285. 
16. Song J, Kwon N, Lee M-H, Ko Y-G, Lee JH, Kim OY. Association of serum phospholipid PUFAs with cardiometabolic risk: Beneficial effect of DHA on the suppression of vascular proliferation/inflammation. Clin Biochem. 2014;47:361-8.

17. Gezer C, Samur G. Omega-3 yağ asitlerinin bilişsel gelişimdeki rolü. Beslenme ve Diyet Dergisi. 2012;40(1):43-9.

18. Calder PC. n-3 polyunsaturated fatty acids, inflammation, and inflammatory diseases. Am J Clin Nutr. 2006;83(6):1505-19.

19. Allaire J, Couture P, Leclerc M, Charest A, Marin J, Lépine MC, et al. A randomized, crossover, headto-head comparison of eicosapentaenoic acid and docosahexaenoic acid supplementation to reduce inflammation markers in men and women: the comparing EPA to DHA (ComparED) Study. Am J Clin Nutr. 2016;104(2):280-7.

20. Arita M. Eosinophil polyunsaturated fatty acid metabolism and its potential control of inflammation and allergy. Allergology International. 2016;65:2-5.

21. Bouwens M, van de Rest O, Dellschaft N, Bromhaar MG, de Groot L, Geleijnse JM, et al. Fish-oil supplementation induces antiinflammatory gene expression profiles in human blood mononuclear cells. Am J Clin Nutr. 2009;9082:415-24.

22. Daci A, Özen G, Uyar İ, Civelek E, Alp Yıldırım Fİ, et al. Omega-3 polyunsaturated fatty acids reduce vascular tone and inflammation in human saphenous vein. Prostaglandins and Other Lipid Mediat. 2017;133:29-34.

23. Kiecolt-Glaser JK, Belury MA, Andridge R, Malarkey WB, Hwang BS, Glaser R. Omega-3 supplementation lowers inflammation in healthy middle-aged and older adults: A randomized controlled trial. Brain Behav Immun. 2012;26(6):988-95.

24. Kiecolt-Glaser JK, Belury MA, Andridge R, Malarkey WB, Glaser R. Omega-3 supplementation lowers inflammation and anxiety in medical students: A randomized controlled trial. Brain Behav Immun. 2011;25(8):1725-34.

25. Flock MR, Skulas-Ray AC, Harris WS, Gaugler TL, Fleming JA, Kris-Etherton PM. Effects of supplemental longchain omega-3 fatty acids and erythrocyte membrane fatty acid content on circulating inflammatory markers in a randomized controlled trial of healthy adults. Prostaglandins Leukot Essent Fatty Acids. 2014;91(4):161-8.
26. Haghiac M, Yang X, Presley L, Smith S, Dettelback $\mathrm{S}$, Minium J, et al. Dietary omega-3 fatty acid supplementation reduces inflammation in obese pregnant women: A randomized double-blind controlled clinical trial. PLoS ONE. 2015;10(9):1-14.

27. Akerele OA, Cheema SK. A diet enriched in longer chain omega-3 fatty acids reduced placental inflammatory cytokines and improved fetal sustainability of C57BL/6 mice. Prostaglandins Leukot Essent Fatty Acids. 2018;137:43-51.

28. Dasilva G, Pazos M, García-Egido E, Gallardo JM, Rodríguez I, Cela R, et al. Healthy effect of different proportions of marine $\omega-3$ PUFAs EPA and DHA supplementation in wistar rats: Lipidomic biomarkers of oxidative stress and inflammation. J Nutr Biochem. 2015;26(11):1385-92.

29. Reifen R, Karlinsky A, Stark AH, Berkovich Z, Nyska A. a-Linolenic acid (ALA) is an anti-inflammatory agent in inflammatory bowel disease. J Nutr Biochem. 2015;26(12):1632-40.

30. Saraswathi V, Heineman R, Alnouti Y, Shivaswamy V, Desouza CV. A combination of omega-3 PUFAs and COX inhibitors: A novel strategy to manage obesitylinked dyslipidemia and adipose tissue inflammation. J Diabetes Complicat. 2020;34(2):107494.

31. Arita M. Mediator lipidomics in acute inflammation and resolution. J Biochem. 2012;152(4):313-9.

32. Chen H. Role of thromboxane A2 signaling in endothelium-dependent contractions of Arteries. Prostaglandins and Other Lipid Mediat. 2018;134:32-7.

33. Derosa G, D’Angelo A, Romano D, Maffioli P. A clinical trial about a food supplement containing a-lipoic acid on oxidative stress markers in type 2 diabetic patients. Int J Mol Sci. 2016;17(11):1802.

34. Islam A, Amin MN, Siddiqui SA, Hossain P, Sultana F, Kabir R. Trans fatty acids and lipid profile: A serious risk factor to cardiovascular disease, cancer and diabetes. Diabetes Metab Syndr. 2019;13:1643-7.

35. Rodrigues HG, Vinolo MAR, Magdalon J, Vitzel K, Nachbar RT, Pessoa AFM, et al. Oral administration of oleic or linoleic acid accelerates the inflammatory phase of wound healing. J Invest Dermatol. 2012;132(1):208-15.

36. Melo RB, de Barros Silva PG, Oriá RB, de Souza Melo JU, da Silva Martins C, Cunha AM, et al. Anti-inflammatory effect of a fatty acid mixture with high $\omega-9: \omega-6$ ratio and low $\omega-6: \omega-3$ ratio on rats submitted to dental extraction. Arch Oral Biol. 2017;74:63-8. 